\title{
Analysis of Chickpea Outlet Choices in Dembia District, North Gondar Zone, Ethiopia
}

\author{
Gedefaw Abebe $^{1,{ }^{*}, \text { Sisay Debebe }}{ }^{2}$, Kalkidan Tesafie ${ }^{3}$ \\ ${ }^{1}$ Department of Agricultural Economics, College of Agriculture and Natural Resource, Bonga University, Bonga, Ethiopia \\ ${ }^{2}$ Department of Economics, College of Business and Economics, Addis Ababa University, Addis Ababa, Ethiopia \\ ${ }^{3}$ Department of Agricultural Economics, Wollega University, School of Graduate Studies, Nekemte, Ethiopia
}

Email address:

abebegedefaw@gmail.com (G. Abebe)

${ }^{*}$ Corresponding author

\section{To cite this article:}

Gedefaw Abebe, Sisay Debebe, Kalkidan Tesafie. Analysis of Chickpea Outlet Choices in Dembia District, North Gondar Zone, Ethiopia. European Business \& Management. Vol. 6, No. 2, 2020, pp. 36-41. doi: 10.11648/j.ebm.20200602.13

Received: May 25, 2020; Accepted: June 8, 2020; Published: June 20, 2020

\begin{abstract}
Chickpea marketing system in Ethiopia is highly immature and poorly organized. This indicates outlet choice is comparatively new and greatly inconstant depending on production situations. The product channeled through complex channel of marketing chains that involve a number of mediators and marketing agents. So, the study was aimed to identify determinant of market outlet choice on chickpea farmers in Dembia district. A two stage sampling technique was used to determine sample size. A total of 150 sample households were randomly selected for an interview using a semi-structured questionnaire and key informants were the other method of data collection. Multivariate probit model was employed to identify the factor affecting chickpea market outlet choices. The result of multivariate probit model showed that literacy status, owning transport facility, livestock holding, chickpea yield and access to extension service significantly influenced the choice of chickpea market outlet choice in the study area. The common underlying factors of market channel choice were also identified. Based on the results, the study recommended that traders, local and national governments, none governmental organizations, policy makers and stakeholders should focus on strengthening the existence formal and informal education, chickpea production system, in improving extension system, strengthening the existing rural telecom and rural-urban infrastructure to achieve good market chain system in the study area as well as at the country level.
\end{abstract}

Keywords: Chickpea Marketing, Ethiopia, Multivariate Probit Model, Outlet Choice

\section{Introduction}

Chickpea (Cicer arietinum L.) was first produced in the Middle East about 7,000 years ago. At present, it is cultivated in above 40 countries of the globe around 11 million ha of land from which over 8 million tons of seed is yearly harvested [14]. The major producers are India, Pakistan, Turkey, Australia, Iran, Myanmar, Canada, Ethiopia, Mexico and Iraq with over 93 percent of the global production. In Africa, chickpea is widely grown in Ethiopia, Sudan, Eritrea, Kenya, Tanzania and Malawi. It contributes around 63 percent of the total production in Africa. In Ethiopia, chickpea ranks third in area coverage from among the pulses grown areas and proceeded by Feba bean and Field pea and second in volume of production only next to Feba bean. In the country, with a total area of $229,720.74$ ha land and the productivity of 1.85 ton per hectare [20].

Chickpea marketing system in Ethiopia is highly underdeveloped and poorly organized. The crop utilization report of CSA indicated that 56.86 percent of total chickpea production was estimated to be allocated for household consumption of the producers and the domestic and export market account for 23.53 percent of the total chickpea volume produced [5]. This implies that the nature of production is subsistence and outlet is relatively new and highly variable depending on production conditions. The viability of the inclusion of chickpea in the exchange is not yet determined by the respective government bodies [9]. The product routed through complex channel of marketing chains that involve a number of intermediaries and marketing agents [15].

Although chickpea is widely grown in Ethiopia, the major 
producing areas are concentrated in the two regional states Amhara and Oromia. These two regions cover more than 90 percent of the entire chickpea area and constitute about 92 percent of the total chickpea production. The top nine chickpea producing zones (North Gonder, South Gonder, North Shewa, East Gojam, South Wello, North Wello, West Gojam, and Gonder Zuria) belong to the Amhara region and account for about 80 percent of the country's chickpea production [6]. So, this study was design to address the prevailing information gap on chickpea market outlet choice and contribute to proper understanding of the challenges and assist in developing improved market development strategies to benefit smallholder farmers.

\section{Research Methodology}

\subsection{Description of the Study Area}

The study was conducted in Dembia district of north Gondar Ababa and $35 \mathrm{~km}$ southwest to Gondar town. The district shares borders with Gondar town and Lay Armachiho in the north, Gondar Zuria district in the east, Chilga and Alefa districts in the west and part of Lake Tana in the south. Dembia district is located at $37^{\circ} 26^{\prime}$ E longitude and $12^{\circ} 17^{\prime} \mathrm{N}$ latitude. Total area of the district is $1490 \mathrm{~km} 2$ with 40 rural and 5 urban smallest administrative units (kebeles) [7].

\subsection{Sampling Technique and Sample Size Determination}

A two stage sampling procedure was employed to select potential chickpea producer households. In $1^{\text {st }}$ stage, five potential producer kebeles was select from 40 chickpea producer kebeles through purposive sampling method based on their production potential. In the $2^{\text {nd }}$ stage, using the population list of chickpea producer farmers from sample kebeles, the intended sample size was determine proportionally to population size of chickpea producer zone, Amhara region. It is located $750 \mathrm{~km}$ north of Addis

farmers. The required sample size was determined by proportionate to size sampling method [4]. I.e $n=\frac{\mathrm{z}^{2} \mathrm{qp}}{\mathrm{e}^{2}}$, where; $n=$ Sample size; $Z=$ confidence level $(\alpha=0.05) ; p=$ proportion of the population containing the major interest, $q$ $=1-p$ and $e=$ allowable error. Hence, $Z=1.96 ; \mathrm{P}=0.11$ $\mathrm{q}=0.89$ and $\mathrm{e}=0.05$, Therefore, $n=\frac{1.96^{2} \times 0.11 \times 0.89}{0.05^{2}}=$ $150.4 \approx 150$

\subsection{Source and Method of Data Collection}

Both primary and secondary data were gathered for this study. Five enumerators were recruited and trained on the content of the questionnaire and interviewing process. Primary data were collected through the administration of semi-structured and personal interview by a team of five trained enumerators to 150 chickpea farmers and secondary data were collected from published and unpublished documents.

\subsection{Method of Data Analysis}

Farmers are more likely to choose the precise combination of market channels to increases their profit and to reduce some risks than a single market channel system. So, a multivariate probit model (MVPM) was used to analyze the determinants of choice of chickpea marketing outlet in the study area [3]. The variance-covariance matrix of the cross-equation error terms has values of 1 on the leading diagonal $\left(\rho_{\mathrm{ji}}=\rho_{\mathrm{ij}}, \& \rho_{\mathrm{ii}}=1\right.$, for all $\left.\mathrm{i}=1 \ldots \mathrm{M}\right)$, the offdiagonal elements have correlations [1]. The selection of one type of market outlet was dependent on the selection of the other, since smallholder farmers choice decisions are interdependent, suggesting the need to estimate them simultaneously [8].

To account for this problem multivariate probit simulation model was employed.

$$
\left\{\begin{array}{c}
\text { Assem }_{\mathrm{j}}=\mathrm{X}_{1} \beta_{1}+\varepsilon^{\mathrm{A}} \\
\text { Whole }_{\mathrm{j}}=\mathrm{X}_{2} \beta_{2}+\varepsilon^{\mathrm{B}} \\
\text { Reta }_{\mathrm{j}}=\mathrm{X}_{3} \beta_{3}+\varepsilon^{\mathrm{C}}
\end{array}=\left(\begin{array}{l}
\varepsilon^{A} \\
\varepsilon^{B} \\
\varepsilon^{C}
\end{array}\right) \sim \mathrm{N}\left[\left(\begin{array}{l}
0 \\
0 \\
0
\end{array}\right)\left(\begin{array}{ccc}
1 & \rho_{12} & \rho_{13} \\
\rho_{21} & 1 & \rho_{23} \\
\rho_{31} & \rho_{32} & 1
\end{array}\right)\right], \mathrm{E}(\varepsilon / X)=0, \operatorname{Var}(\varepsilon / X)=1, \operatorname{Cov}(\varepsilon / X)=\rho\right.
$$

Where Assemj, wholej and Retaj binary variables taking value 1 when farmer $\mathrm{j}$ selects an assemblers, wholesalers and retailers respectively, and 0 otherwise; $\mathrm{x} 1$ to $\mathrm{x} 3$ are vectors of independent variables determining the respective channel choices variables; $\beta^{\prime} s$ are vectors of simulated maximum likelihood (SML) parameters that were estimated; $\mathcal{E}^{\mathrm{A}}$ to $\varepsilon^{C}$ are correlated disturbances in a seemingly unrelated multivariate probit model; and $\rho$ 's are tetrachoric correlations between endogenous variables. In the trivariate case there are eight joint probabilities corresponding to the eight possible combinations of successes (a value of 1) and failures (a value of 0 ).

Table 1. Variables description, measurement and working hypothesis

\begin{tabular}{lll}
\hline Variables & Description & Measurement \\
\hline & & \\
DV & Dependent variables & 1 for assemblers, wholesalers, and retailers, 0 otherwise \\
IV & Independent variables & \\
AGE & Age of household head & Year \\
SEX & Sex of household head & $1=$ male, $0=$ female \\
Nonfinc & None farm income & $0=$ for no, $1=$ for yes \\
LITERACY & Education level & Categorical variable \\
\hline
\end{tabular}




\begin{tabular}{lll}
\hline Variables & Description & Measurement \\
\hline EXC & Extension contact & $0=$ Ho, 1=yes \\
DFM & Distance from market & Walking minutes \\
LMP & Lagged market price & Lagged price of chickpea in birr \\
TQP & Quantity produced & Amount of chickpea produced in quintal \\
LACH & Land allocation to chickpea & land allocated in hectares \\
MINF & Access to market information & $0=$ yes, 1=otherwise \\
CREDIT & Credit access & Amount of credit in birr \\
TLU & Total livestock holding & Discrete variable \\
Own Tran & Owner transport asset & $1=$ Yes, $0=$ No \\
Own corn & Owner ship of communication device & 1 for Owner ship of communication device, 0 otherwise \\
\hline
\end{tabular}

\section{Econometric Results}

\subsection{Diagnosis Tests}

Assembler, wholesaler and retailer market channel choices were considered in this study. Multivariate Probit model was accounted for the interdependence of selection of particular market channels i.e assembler, wholesaler and retailers (Table 2) The Wald chi-square statistic that was used to test the overall significance of the variables included in the model is significant at $1 \%$ level of significance. The likelihood ratio test of the null hypothesis of independence of the market channel choice $(\rho 21=$ $\rho 31=\rho 32=0)$ is significant at 1 percent. Therefore, the null hypothesis of all $\rho$ (Rho) values are jointly equal to 0 was rejected, indicating the goodness-of-fit of the model or the decisions to choose these market channels are interdependent. Hence, the use of multivariate probit model was justified to determine factors influencing choice of market channels. The Simulated Maximum Likelihood (SML) estimation results indicate the $\rho$-values (degree of correlation between each pair of the dependent variables) statistically significant. These were a negative and significant interdependence between household decisions to choose assemblers outlet choice with wholesaler' at 1 percent significance level, and wholesalers with retailers' outlet choice were also positively and significantly interdependent at 1 percent Significance level, but not between consumers outlet and retailers (Table 2).

The marginal success probability for each equation (market channel decision) is reported below. The likelihood of choosing retailer is wholesaler which is low 38 percent as compared to the probability of selecting assembler market channel 56 percent and selecting retailer market channel 47.5 percent.

If chickpea farmers were able to choose all three market channels, their joint likelihood of choosing these market channels would be only 16 percent. It was unlikely for farmers to choose all three market channels simultaneously. This was justified either by the fact that simultaneous chose of all market channels was unaffordable for the smallholders chickpea farmers, or that all three market channels were not more simultaneously accessible in the study areas. However, their joint probability of not choosing all three market channels was 20.2 percent, implying that the households were more unlikely to fail. This evidence suggests that choosing the right mix of market channels determined by different factors for each market channels. This result consistent with food security and agricultural technology interaction studies in Ethiopia by [8].

\subsection{Multivariate Probit Model Result}

Chickpea yield: chickpea yield produced by farmers was associated with a positive effect on farmers' choices among alternative chickpea market channels. A unit increase in farmer's chickpea yield results in an increase in the probability of choosing assembler and wholesaler market channels at 1percent level of significance and retailer market channels at 5 percent level of significance. As the farmers' yield increased by 1 quintal the probability of participating in assembler, wholesaler and retailer market channel increased by $0.08,0.14,0.069$ respectively. Farmer's chickpea yield is the most influential determinant of farmers choices among alternative market cannels, an outlet market with promising relative higher price was influence farmer's choice to supply more of his yield because output price is an incentive for farm households to supply more output for sale which subsequently result in higher income. This result consistent with positive effect of rice yield's on farmer's choices among alternative rice output market [13].

Non- farm income: The likelihood of choosing wholesaler and retailer market channel was also negatively affected by participation in non- farm activities at 5 percent $\& 10$ percent levels of significance, respectively. As the farmer involved in non-farm activities the probability of participating in wholesaler and retailer market channel was decreases by 0.57 \& 0.48 respectively. As farmer involved in non- farm activities their extra time for marketing of agricultural activities and to produce marketable surplus will be less, hence this decreases the probability of participating in wholesaler and retailer market channels. This result consistent with non- farm participation activities negatively influences retail market participation decision [19].

Access to credit: the likelihood of choosing wholesaler was also negatively affected by access to credit at 5 percent levels of significance. As the farmers have access to credit the probability of participating in wholesaler market channel decreases by 0.57 . The possible reason that farmers who choose wholesaler market outlet have no more better access to formal credit. This enables the farmers to choose from alternative market outlet in terms of price advantage, this may be due to financial capability. The result is consistent with access to credit enables farmers to overcome their financial constraints associated with production and adoption 
of innovations and transportation of products to the existing markets [17].

Tropical livestock unit: Livestock holding affects the likelihood of choosing assembler market outlet negatively and significantly at 5 percent probability level. This implies that the likelihood of choosing assembler market outlet decreases by 0.134 for an increase in ownership of livestock by a TLU, keeping other factors constant. Livestock production is one of income generating activity in the rural community by sales of livestock by-products and live animals. This implies that there is an indication in the specialization of livestock production than chickpea production and supply for income generation. This leads to reduce chickpea production and market channel choices. This is consistent with a unit increase of livestock causes a decrease in the volume supply of pepper [18].

Age of household head: Age of household head was to be statistically significant at 10 percent significance level and negatively influenced choice of wholesaler market outlet by smallholder farmers. The results implied that, as age of household head decrease the probability of choosing wholesaler market outlet decrease. The mean age effect showed that, an increase in age of household head by one year decrease the probability of choosing wholesaler market outlet by 0.017 . This is because when households get older and older, they tend to rent out their land or they shift to the production of lesser labour intensive farming alternatives or the younger people are more receptive to new ideas and are less risk averse than the older people. This result in line with age of household head had negative and significance influence on farmers' decision of chickpea market participation [2].

Ownership communication devices: Ownership of communication device had a significant influence on the choice of wholesaler market channel. An increase in the ownership communication device by one unit decrease the probability of selling chickpea to wholesaler's market channel by 0.53 at 1 percent significances level but ownership of communication device direct relation with assembler and retailers. This might be due to the reason that communication device is used to access information and knowledge to strengthen chickpea production and marketing. Raising awareness of chickpea production and marketing through radio and television would have greater impact in increasing market channel choices. This result consistent with ownership of communication equipments such as mobiles, radios and televisions have a positive impact on the market channel choices by facilitating marketing information to the farmers [11].

Ownership of transport assets: This variable influenced the choice of wholesaler outlet positively and significantly at 1 percent significance level. Ownership of transport facilities by farmers increases the probability of choosing wholesalers by 0.836 . This might be due to the reason that, farmers who have transport facility could supply their product to wholesaler. This shows that the availability of transportation facilities may help to reduce long market distance constraint, offer chance of marketing choices [10].

Education level of household head: Education level of households affect retailer channel choice significantly at 5 percent level of significance and had a positive sign. Meaning when farmers become literate the probability of selling chickpea to retailer market channel would increases by 0.396 . Formal education affects their aptitude to access accurate and up-to-date production, market information and their capacity selling of chickpea to other retailer which gives high price [16].

Sex of household head: sex of household head significantly affects wholesaler market outlet choice at 1 percent level of significance positively [12]. As a result, male household heads have more chance to choose appropriate channels than female household heads. Moreover male household heads have more chance to choose appropriate channels than female household heads and male households had a better tendency than female household to participate in the market and volume of supply of chickpea.

Table 2. Multivariate probit model result

\begin{tabular}{|c|c|c|c|}
\hline \multirow{2}{*}{ Variables } & \multicolumn{3}{|c|}{ Coefficients (channel choice equations) } \\
\hline & Assembler & wholesaler & Retailer \\
\hline Owner ship of communication device & -.051 & $-.531 * * *$ & .08 \\
\hline Owner ship of transport asset & -.23 & $.836 * * *$ & .151 \\
\hline Chickpea yield & $.081 * * *$ & $.14 * * *$ & $.0699 * *$ \\
\hline Non-farm income & .103 & $-.57 * *$ & $-.484 *$ \\
\hline Access to extension service on marketing & .042 & .083 & -.1108 \\
\hline Distance to nearest market & $-.0086 * *$ & -.0058 & .0041 \\
\hline Access to credit & .366 & $-.57 * *$ & .301 \\
\hline Lagged market price & .0005 & -.0029 & .00049 \\
\hline Total livestock unit & $-.134 * *$ & .0086 & -.0091 \\
\hline Education level & -.089 & -.136 & $.396 * *$ \\
\hline Land allocation on chickpea production & $.48 * * *$ & .169 & $.297 * *$ \\
\hline Age of household head & -.0065 & -.0026 & $-.0172 *$ \\
\hline Sex of household head & -.366 & .236 & $.763 * * *$ \\
\hline Predicted probability & .561 & .382 & .475 \\
\hline$\rho 21$ & $-.559 * * *$ & & \\
\hline$\rho 31$ & .095 & & \\
\hline$\rho 32$ & $.331 * * *$ & & \\
\hline
\end{tabular}




\begin{tabular}{ll} 
Number of simulations (draws) & 5 \\
Wald chi2 (42) & $113.72 * * *$ \\
Likelihood ratio test of independence & $\mathrm{P} 21=\rho 31=\rho 32=0, \operatorname{chi} 2(3)=19.29 * * *$ \\
Joint probability (success) & .16 \\
Joint probability (failure) & .20 \\
\hline
\end{tabular}

Note: $* * *, * * \& *$ show level of significance at $1 \%, 5 \%$ and $10 \%$ probability level in sequence (Own survey, 2018).

\section{Conclusion and Recommendations}

The result indicated that market outlet choices were positively and significantly influenced by quantity of chickpea. The age of household head negatively and significantly affected market channel. Education level of the household head influenced channel choice positively.

Distance to the nearest market had negatively and statistically influenced decision to market channel choice. The study revealed that the number of livestock holding in terms of TLU influenced channel choices negatively and significantly. Ownership of communication device by the head of the household was found to be an important factor for choice of market channel negatively and significantly. Land allocated to chickpea affected channel choices positively and significantly. Ownership of transport facility has influenced market channel choice positively. Non-farm income has affect market channel choices negatively and significantly.

Access to market information affected choice positively and significantly. Sex of household head affects market channel choice positively. From these findings appropriate policies should be designed to provide adequate and effective basic educational opportunities to the rural farming households in general and to the study area in particular. In this regard, the regional and local government should strengthen the existing provision of formal and informal education through facilitating all necessary materials.

Access to communication device (ownership of radio, TV, mobile) should be strengthened in order to ensure accurate information is available and widely disseminated. As a result, policies and strategies should place more emphasis on strengthening the existing rural telecom and rural-urban infrastructure development of the study areas by the regional and local government.

Interventions intended at reducing transaction costs through rural infrastructure investment in the form of establishing all weather road, improving market information delivery system in order to avoid information asymmetry, improving smallholder farmers access to credit though strengthening rural micro finance and encouraging membership in cooperatives are vital area of intervention that would assist farmers to choose the more rewarding market outlets.

\section{Competing Interests}

There are no competing interests.

\section{Funding}

Authors have n't gotten direct fund for this research work.

\section{Abbreviations}

CSA: Central Statistical Authority; DDFEDO: Dembia District Agriculture and Rural Development Office; MoARD: Ministry of Agriculture and Rural Development.

\section{Acknowledgements}

The authors are valued ministry of education, enumerators and target respondents of the study area for their valuable information for the achievement of this study.

\section{References}

[1] Abebe, G., \& Debebe, S. (2020). Determinants of recommended agronomic practices adoption among wheat producing smallholder farmers in Sekela district of west Gojjam zone, Ethiopia. Journal of development and agricultural economics, 12 (1), 17-24.

[2] Adugna. (2009). Analysis of fruit and vegetable market chains in Alamata, southern zone of Tigray: the case of onion, tomato and papaya. An M. Sc thesis presented to school of graduate studies of Haramaya University. Pp98.

[3] Cappellari and jenkins. (2003). Multivariate probit regression using simulated maximum likelihood', stata j, 3 (3): 1-17.

[4] Cochran's. (1977). Sampling techniques, 2nd ed., new york: john wiley and sons, inc.

[5] Csa. (2007). Area and production of crops. Country level, part ii, Addis Ababa. Pp. 261-323.

[6] Csa. (2015). Central statistics authority-Ethiopia. (2015). Report on area and production of crops. Statistical bulletin. 1: 578-589.

[7] Ddfedo. (2017). (dembia district finance and economic development office). (2017). Working paper of dembia district agro-ecology and its habitat.

[8] Degye et al. (2013). Degye, g,. Belay k. And mengistu k, (2013). Is food security enhanced by agriculturaltechnologies in rural Ethiopia? African journal of agricultural and resourceeconomics volume 8 number pages. 58-68.

[9] Haile. (2010). Chick pea production, supply, demand and marketing issues in Ethiopia. Ethiopian commodity exchange authority. Economic analysis work process of ecea Addis Ababa.

[10] Jagwe. (2007). Impact of transaction cost on the participationof smallholder farmers and intermediaries in the banana market in burundi, democratic.

[11] Key, n., sadoulet, e. And dejanvry, a. (2000). Transactions costs and agriculturalhousehold supply response. American journal of agricultural economics, 88 (2):. 245-259. 
[12] Kinde. (2007). Sesame market chain analysis: the case of Metema woreda, north gondar zone, Amhara national regional state. An M. Sc thesis presented to schoolof graduate studies of Haramaya University. 123p.

[13] Maryam. (2015). Analysis of rice farmers' access to output market and profit efficiency in Kano state, Nigeria a thesis submitted to the school of postgraduate studies Ahmadu Bello University, Zaria.

[14] Menale et al. (2010). Adoption and impact of improvedgroundnut varieties on rural poverty: evidence from rural Uganda. Environment for development (efd), discussion working paper, may 2010 efd dp 10-11.

[15] Moard. (2010). Annual report of 2009/2010 Addis Ababa, Ethiopia.

[16] Mukiama, b., k, nongluck. s and yaowarat. s. (2014). Factors influencing vegetable farmer's choice of marketing channel in khon kaen, Thailand. Khon kaen agr. j42 (4). 595-604.
[17] Mussie, a., j. Mwanga, w. Mwangi, h. Verkuijl, r. Mungi and a Elang. (2001). Adoption of improved wheat technologies by small scale farmers in Mbeya district, southern high land. Tanzania: international maize and wheat improved centre (cimmyt) of the united republic of Tanzania.

[18] Rehima Musema. (2009). Analysis of red pepper marketing: the case of Alaba and Silitie in SNNPRs of Ethiopia. An M. Sc. Thesis presented to school of graduate studies of Haramaya University. 153p.

[19] Tewodros. (2014). Analysis of chickpea value chain and determinants of market options choice in selected districts of southern Ethiopia. Journal of agricultural science; vol. 6, no. 10; 2014 issn 1916-9752 e-issn 1916-9760.

[20] Tl-iii. (2016). (tropical legumes iii. (2016). Chickpea production, technology adoption and market linkages in ethiopia. Pan-Africa grain legume and world cowpea conference feb 28- mar 4, 2016, livingstone, Zambia. 